\title{
CAPACITY DEVELOPMENT AND EDUCATION OUTREACH IN GEOINFORMATICS AND LAND MANAGEMENT: A CASE OF DEPARTMENT OF GEOMATICS ENGINEERING, KATHMANDU UNIVERSITY
}

\author{
S. Ghimire \\ Department of Geomatic Engineering, Kathmandu University, 45200 Dhulikhel, Nepal - subash_ghimire@ku.edu.np
}

Commission V, WG V/7 \& Commission IV, WG IV/6

KEY WORDS: Capacity Development, Geoinformatics, Land Management, Geomatics Engineering Department, Nepal

\begin{abstract}
:
The capacity development and education outreach in Geoinformatics and Land management is very important for the development of any country. The aim of this paper is to highlight the existing capacity development and education outreach in Geoinformatics and Land Management at Department of Geomatics Engineeringand draws attention of all national and international geospatial community for their contributions to promote capacity development and education outreach in Geoinformatics and Land Management sectors in Nepal. The desk study has been carried out for the study by reviewing literature and using secondary data sources. This study analyzes an aspects, challenges and opportunities in collaborative efforts made by Kathmandu University and Land Management Training Center to become a center of excellence in these sectors. The study reveals that "To make Geoinformatics and Land Administration, a leader course in Nepal and also within the region”, Kathmandu University has to overcome various challenges. Some challenges may be addressed in the national level but some require collaborations and cooperation from international geospatial community. The result indicates thatthe capacity development and education outreach in Geoinformatics and Land Management sector helps to develop quality geospatial professionals which in turn may incorporate the entire South Asia region as a potential Geospatial and Land Management market. Finally, Kathmandu University, Department of Geomatics Engineering is committed to develop a centre of excellence in Geoinformation and Land management sector by providing quality education, research and development.
\end{abstract}

\section{INTRODUCTION}

The capacity development and education outreach in Geoinformatics and land management is very important for the development of any country.Kathmandu University (KU) was established in November 1991 as an autonomous, non for profit, non-government, dedicated to maintain high standards of academic excellence, public institution through private initiative. The university is committed to develop leaders in professional areas through quality education with the vision "To become a World Class University devoted to bringing knowledge and technology to the service of mankind". It is committed not only to develop leaders in professional areas through quality education but also develop as a centre of excellence. Long term presence of the university is also intended to benefit the local communities in terms of development of small scale business and community services (Ghimire, 2016). As silver Jubilee initiatives, it focuses on Quality, Innovation, Impact, Engagement, Equity and Identity.There is seven schools in the university: School of Engineering,School of Management, School of Science, School of Arts, School of Medical Sciences, School of Education and School ofLaw. School of Engineering has Department of computerscience and Engineering,Department of mechanical Engineering, Department of electrical Engineering, Department of Chemical Engineering, Department of Civil Engineering and Department of Geomatics Engineering.Department of Geomatics Engineering is the youngest Department of School of Engineering and is officially established on March 26, 2019.
The aim of this paper is to highlight the existing capacity development and education outreach in Geoinformatics and Land Management at Department of Geomatics Engineering and draws attention of all national and international geospatial community for their contributions to promote capacity development and education outreach in Geoinformatics and Land Management sectors in Nepal.

\section{METHODOLOGY}

The desk study has been carried out for the study by reviewing literature such as journal articles, proceedings, reports etc. and is given in reference section and by using secondary data source such as brochure, report etc.

\section{ASPECTS OF GEOMATICS EDUCATION}

An aspects of Geomatics Education such as teaching/learning, vision, existing status of undergraduate Geomatics Engineering, existing physical facilities, status of graduate programs, ongoing research projects and capacity on organizing workshop. are discussed in following subsections.

\subsection{Teaching/ Learning}

Kathmandu University (KU) in collaboration with Land Management Training Center (LMTC) has started undergraduate Bachelor of Engineering in Geomatics Engineering in 2007 and successfully running under the framework of Memorandum of understanding (MOU) between KU and LMTC. KU and LMTC also share the physical boundary and resources to promote undergraduate and graduate 
programs:Geoinformatics and Land Administration (Ghimire, 2015).

Mainly LMTC under the Ministry of Land Management, cooperatives and poverty alleviationis established to produce the skillful surveying, mapping and landadministration and management professionals through trainings within thecountry.LMTC is offering two types of regular courses and several short courses; Basic Survey course and Senior and Junior Survey course.

Department of Geomatics Engineering offers Diploma in Geomatics Engineering started in 2015 in collaboration with LMTC and CTEVT, Bachelor in Geomatics Engineering started in 2007, Master in Land Administration started in 2013 and ME/MS in Geoinformatics is started from 2019. PhD program will be started based on need and availability of supervisors.

\subsection{Vision}

Department of Geomatics Engineering has set its vision "To become centre of excellence by providing quality education and research for leadership in Geoinformaticsand Land sector in joint cooperation with government and other collaborating organizations."

Department of Geomatics Engineering in KU and LMTC has set following future plan to fulfil its vision:

- To strengthen all levels of education in Geomatics Engineering to produce operational and managerial level highly qualified skilled human resources.

- To start MS by research in Geoinformatics and Land Administration and management.

- To enroll more PhD candidates in the field of Geoinformatics and Land administration and management.

- To strengthen and develop the intern opportunity for Geomatics Engineering students in related industries.

- To strengthen Geo Spatial Lab, photogrammetry and surveying lab and establish cartography lab.

- To carry out more research projects in collaboration with collaborating national and international organizations.

- To promote student/staff/faculty exchange program.

\subsection{Status of undergraduate Geomatics Engineering}

The undergraduate Geomatics engineering program was started in August 2007. Total 270 students are graduated as Geomatics Engineers and most of them are already employed in various government and non-government institutions. The first MOU between KU and LMTC under the framework of which, the Geomatics program had been started was completed with the intake of 2010 batch and a second MOU is completed in 2015 and third MOU with the intake of 2018 batch. Under first completed MOU, Ministry of Land Reforms and Management have provided financial support for 7 years for four batches. In this case $75 \%$ of total fee is waived for 24 students. Similarly, under the framework of second MoU, 2011, 2012, 2013 and 2014 batch students wereenrolled in the course. The Ministry of Land Reform andManagement had provided scholarships under various categories to number of students. In the second and thirdMOU, $100 \%$ tuition fee is waived for two students from government employee in theengineering services under survey group category, a 50\% fee is waived for eight students from four Development Regions except the central regions of Nepal and 33\% of tuition fee is waived for 10 students passing the Kathmandu University Common Admission Test (KUCAT) entrance exam on merit basis. The total graduated students are: 203 (8 Batches) and 9th batch is graduated this year. Currently, 150 (4 Batches) students are studying BE in Geomatics Engineering and fourth MoU provisioned 35\% scholarship for 21 students based on inclusive provincial category (KU \& LMTC, 2019).

\subsection{Physical Facilities}

The library facilities, sports facilities, computer Lab for computer programming, Geospatial lab, photogrammetry and surveying lab and conference lab for provision for e-learning are available at $\mathrm{KU}$. The course syllabus of BE Geomatics Engineering program is consistently revised by the Subject Committee/Faculty board and academic council of KU with due consideration of feedback from students and stakeholders including industries every year. This engineering program have strong component of field survey training equivalent to 4.5 months in 4 years program and internship of one and half months

\subsection{Graduate programs}

Department of Geomatics Engineering has following two graduate programs and are discussed in following subsections.

\subsubsection{Master in Land Administration}

KU has started two year's master degree program in 2013 in Land Administration in collaboration with LMTC and is successfully running at KU. The main aim of starting the master in land Administration course is to produce graduate level highly skilled and qualified professionals in the field of land Administration and to conduct and promote research and development activities in the field of land administration and management. Land administration program at KU consists of multidisciplinary courses so that the intake will be from multidisciplinary background. The Government of Nepal has approved $100 \%$ scholarship to 5 candidates for government employee up to four batches. The financial aid is also available to selective full paying students in the form of graduate teaching assistantships as per the requirement of the Department.

\subsubsection{ME_MS in Geoinformatics}

Department of Geomatics Engineering has also started two year's ME/MS degree inGeoinformatics from 2019 in collaboration with LMTC and is successfully running at KU. The main aim of starting the ME/MS in Geoinformatics is to produce graduate level highly skilled and qualified professionals in the field of Geoinformatics and to conduct and promote research and development activities in the field of Geoinformatics. 


\subsection{Research Projects}

Department of Geomatics Engineering had carried out several research projects as follows and includes following activities.

1. Strengthening Geospatial Infrastructure and Research Capacity at Kathmandu University funded by NASA through ICIMOD

2. Developing Demonstration Model to Revive Springs for Enhancing Rural Water Security funded by Oxfam.

3. Land Surface temperature change analysis of Kathmandu Valley using Landsat images funded by UGC

4. Developing Land Valuation model for Land Acquisition in Infrastructure Developement. A livelihood perspective funded by NAST.

5. Estimation of Above Ground Forest Biomass and Carbon Stock Using UAV Images funded by NASA through ICIMOD

6. Maize Biomass Estimation Using Images from Unmanned Platform using Consumer Grade RGB Camera funded by UGC and The International Maize and Wheat Improvement Center (CIMMYT)

7. Inspection of transmission line infrastructure for Bhaktapur-Baneshwor-Patan-66kV.

8. Transmission Line Upgradation Project funded by NEA Engineering Company

9. Survey and mapping of Jagdulla Hydro-Electric Project funded by NEA Engineering Company

10. Geonode Project funded by World Bank

\subsection{Training/Workshop/ Refresher course}

Department has organized following workshop and refresher courses

- $\quad$ Adopting Geo-ICT for Land Administration, 15 - 19 June, 2009

- Training for trainers in transparency in Land Administration, 2010

- Preconference Event: International conference on Role of Land Professionals and SDI in Post Disaster Risk Reduction, organize by FIG, ISPRS, NICS and NSPRS, 25- 27, November 2015 ( KU, 2019).

- International Workshop on 'Flight 4 Purpose' Jointly organized by Department of Geomatics Engineering, Kathmandu University and Kadastre International, Netherlands. 2019.

\section{CHALLENGES}

The major challenges of undergraduate Geomatics Engineering and graduate ME/MS in Geoinformatics and Master in Land Administration in Kathmandu University are highlighted as follows.

- Infrastructure development

- Hardware and software

- Faculty expansion visiting experts (national/international)

- Knowledge exchange programs

- Expansion of further higher education and job market (Bhattarai, 2009).

\section{OPPORTUNITIES}

There is an ample of opportunities for Department of Geomatics Engineering to become a centre of excellence in Geoinformatics and Land Administration Sector. Institutions like UT/ITC, University of Salzburg,Austria, Yildz Technical University, Turkey, ICIMOD, private and government agencies are willing to support Departmentof Geomatics Engineering to achieve its goal. Department of Geomatics Engineering has expectations for expert advice from national and international Geoinformatics and land administration community (Ghimire, 2011).

\section{INTERNATIONAL COLLABORATION}

Department of Geomatics Engineering has collaborations with following organizations

- Faculty of ITC, University of Twente, the Netherlands

- University of Salzburg, Department of Geoinformatics, Austria

- Department of Geomatics Engineering, Yildiz Technical University, Turkey

- ChanganUniversity,China

\section{CONCLUSIONS}

Geoinformatics and Land Administration has become an emerging field as it directly deals with surveying, mapping and land management. Department of Geomatics Engineering, KU in collaboration with LMTC is playing crucial role for it. To become a centre of excellence in Nepal and also within the region in the future, Department of geomatics Engineering has to grab the opportunities and overcome the challenges. Some of the above mentioned challenges could be addressed in national level but some requires cooperation and collaboration from the international level. Therefore, it is essential to draw attention of all national and international Geoinformation and land administration and management community for their contributions to promote education and research and development in these sectors in Nepal.

\section{REFERENCES}

Bhattarai, N., 2009. Geomatics Engineering Education in Kathmandu University: Issues and Challenges, 7th FIG Regional Conference Spatial Data Serving People: Land 
Governance and the Environment - Building the Capacity Hanoi, Vietnam, 19-22 October.

Ghimire, S., 2016. Capacity Building in Geo information Sector: A case of Kathmandu University. Nepalese Journal of Ge informatics, Annual publication of Survey Department, Government of Nepal, 15. Retrieved from http://dos.gov.np/wpcontent/uploads/2016/07/Nepalese-Journal-on-GeoinformaticsV15.pdf

Ghimire, S., 2015. Geomatics Education and Research Enhancement at Kathmandu University. Nepalese Journal of Geoinformatics, Annual publication of Survey Department, Government of Nepal, 14, 14-17

Ghimire, S., 2011. The Role of Geomatics Engineering Education for National Development. Proceeding of the 2011 International Symposium on Advanced Engineering, Busan, Korea

KU \& LMTC, 2019. Memorandum of Understanding signed between KU and LMTC.

KU, 2019. Geomatics Engineering Admission Brochure, Published by Department of Geomatics Engineering. Internet 1: http//geom.ku.edu.np/ (Accessed on October 02, 2019 